\title{
When the successor becomes the true leader of a family business?
}

\author{
Alicja Hadryś-Nowak
}

\section{A B S T R A C T}

Objective: The aim of presented paper is to try to answer to the questions: what are the factors that facilitate or inhibit the process of becoming the leader for international family business, and what are the major successor's characteristics enabling successor to be a true leader of international family business?

Research Design \& Methods: The in-depth interview method was used.

Findings: Successor's characteristics such as: integrity, commitment to the family and family business, ability to command the respect of the personnel, decisiveness and interpersonal skills, proved to be relevant.

Contribution \& Value Added: With the study, author aim to contribute to a better understanding of factors connected with successor's passage from manager to leader in international family business. the successors need to feel responsibility for the family. Secondly, he/she should has the deciding power in some part of the business. As case study shows, conflicts and interactions between family members, when well-managed, might be source of new ideas and solutions. Next to qualifications and constant learning and improving skills, there is also a need for being open minded and ready to change.

\begin{tabular}{|c|c|}
\hline Article type: & research paper \\
\hline Keywords: & $\begin{array}{l}\text { succession process; successor; family business; business transfers; } \\
\text { generational change }\end{array}$ \\
\hline JEL codes: & M12, M51, M53, L26 \\
\hline Article received: 1 February 2020 & Article accepted: 4 April 2020 \\
\hline
\end{tabular}

\section{Suggested citation:}

Hadryś-Nowak, A. (2020). When the successor becomes the true leader of a family business?. International Entrepreneurship Review (previously published as International Entrepreneurship / Przedsiębiorczość Międzynarodowa), 6(1), 77-92. https://doi.org/10.15678/IER.2020.0601.05

\section{INTRODUCTION}

Leadership succession is a significant challenge for all family businesses. Despite this many family businesses do not have clear plans nor systematic processes for implementation trans-generational change (Fang et al., 2015). Some family business owners believe that succession is natural process and successors became leaders naturally. If that was it, then 
more than $30 \%$ would survive the first generation, around $15 \%$ would survive to the third generation, and more than $3 \%$ would survive to the fourth generation (Vera \& Dean, 2005). Although, research has been dedicated to family business succession and preparing successors, there is still no in depth research showing the path needed to cross from successor to be a true leader in family firm. The idea that a family business succession can have an impact on the financial structure and performance of a firm should be no surprise given that a business transfer is one of the most important and critical events in the life cycle of family firm. It is therefore important to study business transfers. This can lead to more insights into best practices regarding how to carry out a succession and on the way in which the business is expected to change because of the transition event. Martin and Lumpkin (2004) find that in successive generations entrepreneurial orientation tends to diminish and give way to family orientation, as stability and inheritance concerns become the business's principal drivers. Central in the succession process is that the management of the family business end up in the hands of a competent and well-motivated successor. Succession process has the potential to disrupt and even to destroy successful businesses, irrespective of their financial or market power (Bozer et al., 2017) but in some cases a succession, particularly when an successor is involved, can lead a family business to new markets, new ways of acting and thinking (Graves \& Thomas., 2008; Ibrahim et al., 2001; Menendez-Requejo, 2005). Assuming the topic of succession is one of the most critical challenges in the family business literature, this paper attempts to address the factors that act as driving forces for the successor to become a leader of international family businesses. The following research questions are posted:

RQ1: What are the factors that facilitate or inhibit the process of becoming the leader for international family business?

RQ2: What are the major successor's characteristics enabling successor to be a true leader of international family business?

Succession planning has scope for the personal approach especially exploring people's stories and narratives and case histories. Working with individuals or small groups in an in-depth interview is the type of research needed in this area. That is why a qualitative approach was used.

\section{LITERATURE REVIEW}

Author selected agency and stewardship theory as the theoretical framework. The conceptual domain of agency theory is one of the dominant organisational theory perspectives applied in current family business research (Chrisman et al., 2010, 2010). According to agency theory (Jensen \& Meckling, 1976), agency costs generally arise due to individuals' self-interest and decision making based on rational thinking and oriented toward own preferences. With more people involved in decision-making, such as through the separation of ownership and management, agency costs occur due to different preferences and information asymmetries between the owner (principal) and the employed management (agent) (Jensen \& Meckling, 1976). In other words, agents take decisions based on their individual preferences (e.g., short-term, financial gains) instead of the owners' preferences (e.g., long-term, sustainable development). For this research, the principal-principal approach was used. This constellation also raises problems determining who is responsible 
and has the power to control and make decisions (Morck, \& Yeung, 2003). In family firms, this situation can additionally be complicated by the emotional and relational attitudes of the involved family members (Gómez-Mejia et al., 2007; Schulze et al., 2003), which can eventually lead to a suboptimal economic outcome overall (Shukla et al., 2014). To delimit agency theory from other theoretical approaches, an often opposed and more collectivistic theory from the economic literature is stewardship theory (Davis et al., 1997). The stewardship perspective addresses the behaviour of controlling family firm owners that behave as far seeing stewards and are guided by superior organisational goals (Sharma, 2004). Several authors discuss the applicability of agency theory in comparison to stewardship theory in family firms and argue that both theories contribute important insights to the knowledge about family firms (Chrisman et al., 2007; Corbetta, \& Salvato, 2004; Eddleston, \& Kellermanns, 2007; Kraus, Märk, \& Peters, 2011; Le Breton-Miller, Miller \& Lester, 2011). Stewardship theory states that the agents ("stewards") behave socially, in a self-actualizing manner and with an attitude postulating psychological ownership (Pierce et al., 2001). It recognizes that many family leaders are loyal stewards of their firms, contributing to firm performance through citizenship behaviors (Drakopoulou et al., 2015. Banalieva and Eddleston (2011) believe that kinship, a shared family name, and common history promote a shared identity that allows family leaders to build an enduring reputation and social capital that can be passed from one generation to the next. Presented case study will show that at the beginning of their career path, successors may act as an agent in family business. However, to become true leaders transformation to "stewards" is needed. Author will try to capture factors needed to this passage from agent to steward.

Succession is a key determinant of generational continuity. However, succession is not just a step of passing the baton, but instead it is a process that develops over several stages that evolve over time and, in some cases, begin even before the successor enters the business (Handler, 1994). Given the importance of continuity in the family business, the succession process has drawn the attention of researchers who have tried to identify those variables driving an effective succession. It has been predominantly studied through the lens of single organizational source, such as incumbents, successors, and nonfamily employees (Decker et al., 2017). The succession process encompasses a number of factors which are usually associated with both the predecessor and successor. Due to the purpose of the article, issues relating mainly to the successor will be discussed. Among these factors, quality, harmony of family relations, organizational culture and succession planning have been emphasized in relevant literature. After a qualitative study with 32 family businesses, Handler (1994) found that mutual respect and a common vision between the founder and successor are very important components of an effective succession. Several authors also stress the importance of personal and professional realization of family members (Dunn, 1995). Existing research on the impact of a succession on the performance of a family firm is still inconclusive. Some authors argue, that performance is lower of next-generation family firms, others come to opposite conclusions. Moving from one generation to another, means goal change, which can result in stagnation. First generation family firms are more business oriented than are later generation firms, which are more family oriented, and firms with a business orientation have a higher capacity to grow (Dunn, 1995; Cromie et al., 1995; Reid et al., 1999). Similarly, Martin and Lumpkin (2004) find that in successive generations entrepreneurial orientation tends to diminish and give way to family orientation, as stability 
and inheritance concerns become the business's principal drivers. Davis and Harveston $(1998,1999)$ further show that the "generational shadow" cast by the founder is much greater than the generational shadow cast by subsequent generations. They state that the transition between the founder and the second generation can often be seen as the most difficult and turbulent one. Lately, business literature has increased its interest in the way of top managers play an essential role in shaping organizational outcomes (Carpenter at all.,2004; Hambrick \& Mason, 1984; Loane, Bell, \& McNaughton, 2007). According to Hambrick (2007) the best way to understand why organizations do and/or perform the things they do, it is fundamental to consider the biases and dispositions of their most powerful actors - their top executives. The base of these assumptions is on the upper echelons theory proposed by Hambrick and Mason (1984). It is based on the idea that managerial characteristics can be a useful measure to predict organizational outcomes. This theory argues that executives act on the basis of their personalized interpretations of the strategic situations they face, influenced by their cognitive base and their values. It indicates a person's values, skills, knowledge base and information processing abilities influences the decisionmaking process (Hambrick, 2007). Overall, based on the above literature, the negative effect of succession on firm performance is expected to occur unless the successor is a true family business leader not only appointed manager.

Successors strongly supported the notion that early exposure to the family business had a positive effect on their commitment to adopt a leadership role (e.g. Klein et al., 2005). Internal exposure was a greater benefit for them than working outside the family business, because it facilitated idiosyncratic family-business knowledge transfer. All successors highlighted higher education as potentially beneficial to succession, especially if that education was relevant to the business (see Morris et al., 1997). Both successors and incumbents acknowledged that established protocols, formalized structures, and family culture helped nurture a successful succession (e.g. Cabrera-Suárez et al., 2001). Successors also noted the importance of an accepting, open, transparent communication structure between the incumbent and themselves. However, successor and incumbent perceptions of the value of consistent, formalized structures differed significantly. Successors viewed these characteristics as potential barriers to establishing a leadership style and culture and a hurdle for a successful succession. Additionally, unlike incumbents, who viewed nonfamily members' influence as a possible dilution of the FBS characteristics (Ensley \& Pearson, 2005), successors placed importance on the influence of nonfamily employees in the succession process and viewed their contributions as making a positive impact on their succession.

As this study was conducted in Poland, some specificities of this institutional context need to be pointed out. The Polish context is very interesting because with the collapse of the old regime in 1989, the outburst of entrepreneurship resulted in the creation of numerous family businesses which became the backbone of the blossoming free-market economy (Bednarz et al., 2017; Campbell \& Jerzemowska, 2017). In 1989 the system changed and private business became legal which resulted in setting up private enterprises at a massive scale. It was the period when many family-owned businesses came into being. A vast majority is still operating and in good condition. Within the framework of these studies the distribution of family-owned businesses in Poland was checked. The majority of them are the micro firms which have been operating locally for some 10-20 years, 
whose owner is a man, and which have no separate management board within their organizational structure. These firms operate in the wholesale and retail sector as well as in the industry ("Family Business is a brand", IBR 2017). Ownership in Poland plays a special role in business, and it can be a factor stimulating the internationalization of firms (Wach, 2017). In family businesses the family ownership plays a crucial role.

Most of Polish family businesses are still in the first generation phase, so called 'founder stage". The first succession process is happening and there is no tradition for family business succession.

\section{MATERIAL AND METHODS}

In line with recent calls form more qualitative, explorative research on business development processes (Davidsson et al., 2010; Doern, 2009), a qualitative method was chosen for this study. The data was generated through in-depth, semi structured, open-ended interview with successor, CEO of medium family business (second generation). Interview lasted over 3 hours. This qualitative study is the result of previous quantitative studies conducted by the author (ex. Hadryś-Nowak, 2018; Więcek-Janka \& Hadryś-Nowak, 2016). Interview was more as a story told by the successor supplemented by answers to additional questions made by the author. The interview was divided into two parts. First part corresponded to the question Q1: What are the factors that facilitate or inhibit the process of becoming the leader for international family business? The second part corresponded to the question Q2: What are the major successor's characteristics enabling successor to be a true leader of international family business? Instead of undertaking the interviews, the author gathered non-participant observations and archival documents, such as: contracts, websites, protocols, strategy book, ISO handbook, CSR Report etc. The author assisted during family and business meetings (ex. in Ślesin, Poland, 2018-03-06). The selection of the analysed company and its successor was made based on relations built during previous projects.

\section{RESULTS AND DISCUSSION}

\section{Presentation of the company}

The company: HORTIMEX PLUS Sp. z o.o. Spółka Komandytowa

Founder: Tomasz Kowalewski (Father), owns 65\% of the company

Successor, current CEO: Mateusz Kowalewski, owns 35\% of the company

Nowadays, Hortimex is a specialised company that is a platform for the exchange of goods, know-how, and experience between the worldwide producers of food ingredients and the Polish ones. For about 30 years they have been providing food producers in Poland with technological consultancy in the creation of new food products and the selection of the finest ingredients and the best solutions. Hortimex is a family company. That is why they rely on trustworthy business relationships, which are beneficial for every party to a deal. They help producers of food ingredients by:

- assistance in entering the Polish market;

- sales \& distribution of food ingredients to food producers in the whole country;

- development $\&$ improvement of business relationships with producers. 
Hortimex also help food producers by:

- consultancy in developing unique and appealing recipes for food products;

- search for desirable ingredients among products offered by foreign producers;

- supply of tested, natural, and appealing food ingredients to food production facilities. Hortimex's customers value them most for:

1. Effectiveness. Thanks to their experience they have been gaining for almost 30 years they know how to effectively convince food producers in Poland to try and use new ingredients.

2. Flexibility. Each of their customers can be sure that they efficiently tailor their services to individual preferences, plans, and expectations. Flexibility is their middle name.

3. Promptness. In times of intense competition it is essential to carry out a project promptly. They know that. That is why they act skilfully and timely.

Mission of the company:

"We rely on the education of the food production market and professional consultancy in it. We believe that together we will be able to improve the quality of the Polish food production market as well as to create a friendly, healthy, and costeffective market. In fact, we are all consumers".

"We would like to see better and better products on the shop shelves - more delicious, more aromatic, and more healthy and functional. Therefore, we help Polish companies introduce new food products to the market and worldwide producers of food ingredients present their semi-finished products to Polish producers".

How the story begins...

"Hortimex is a family business managed by the second generation of owners. Founded in 1988 by my parents, Lucyna and Tomasz Kowalewski, for many years it was built and managed in the spirit of broadly understood responsibility. Both, me and my father who managed the company were very serious to liabilities to contractors, employees, local community and other stakeholders. The years 20092013 are the period of succession in company management. We worked it out then and we implemented the management system strategic and first structured strategy for the company, which we called 'Hortimex 2015'. In addition to obvious business activities it assumed continuation and strengthening values that helped in building enterprise development". 
Table 1. Scale of activities

\begin{tabular}{|c|c|c|c|}
\hline Criteria & 2014 & 2015 & 2016 \\
\hline Employees & 30 & 32 & 30 \\
\hline Turnover (net, PLN) & 46645040,32 & 61563795,08 & 62747612,28 \\
\hline $\begin{array}{l}\text { Capitalization from a } \\
\text { perspective } \\
\text { own contribution (\%) }\end{array}$ & 1,7 & 1,7 & 2,1 \\
\hline Assets & 14206197,69 & 16309660,59 & 16767725,87 \\
\hline Shareholders & $\begin{array}{l}\text { Tomasz J. Kowalewski, } \\
\text { Mateusz } \\
\text { Kowalewski, } \\
\text { Spółka Plus }\end{array}$ & $\begin{array}{l}\text { Tomasz J. Kowalewski, } \\
\text { Mateusz } \\
\text { Kowalewski, } \\
\text { Spółka Plus }\end{array}$ & $\begin{array}{l}\text { Tomasz J. Kowalewski, } \\
\text { Mateusz } \\
\text { Kowalewski, } \\
\text { Spółka Plus }\end{array}$ \\
\hline Value & 1204898,13 & 2484487,00 & 2726732,53 \\
\hline Countries & $\begin{array}{l}\text { Austria, Belgium, China, } \\
\text { France, } \\
\text { Spain, the Netherlands, } \\
\text { India, } \\
\text { Ireland, Canada, Lithua- } \\
\text { nia, Germany, } \\
\text { Norway, Poland, Turkey, } \\
\text { Hungary, Great Britain, } \\
\text { Italy }\end{array}$ & $\begin{array}{l}\text { Austria, Belgium, China, } \\
\text { France, } \\
\text { Spain, the Netherlands, } \\
\text { India, } \\
\text { Ireland, Canada, Lithua- } \\
\text { nia, Germany, } \\
\text { Norway, Poland, Turkey, } \\
\text { Hungary, Great Britain, } \\
\text { Italy }\end{array}$ & $\begin{array}{l}\text { Austria, Belgium, China, } \\
\text { France, } \\
\text { Spain, the Netherlands, } \\
\text { India, Ireland, Canada, } \\
\text { Lithuania, Germany, } \\
\text { Norway, Poland, United } \\
\text { States United States, } \\
\text { Turkey, Hungary, Great } \\
\text { Britain, Italy }\end{array}$ \\
\hline
\end{tabular}

Source: own study.

\section{Values \& HR Policy}

The Hortimex team is small and quite well integrated. The team composition is shaped primarily on the participants' compliance with the company's culture. Competences, however very important, they are not the only one, but one of the employee evaluation criteria. Managers are significantly involved in the communication process and shaping attitudes. Therefore, we decided that it is not there the need to create additional structures or channels of communication, dedicated to the responsible person proceedings. Rules of conduct are shaped by Quality Policy, management areas policies and individual procedures (under the ISO 9001: 2008 system). The owners decided to open debate about values and attitudes. During several workshops in which the whole company was involved, they selected five essential values that recognized the most important. They are: responsibility, openness, respect, honesty and trust. As far as they anticipate the possibility expanding or modifying it. Reported by the team as important, it became the subject of a workshop, which took place in October 2016. As a consequence, it was formulated document "Rules of giving and receiving gifts in business relationships".

"If we want to answer what decided our position, I think that it is a mix of many factors. However, I have the certainty that it is decisive that we do a lot of things differently"(employee statement).

"What is the key in our activities? Why is it worth working together and relations with our partners and recipients are essential for us? Is Hortimex just a company or something more? I chose nine features and values that are fundamental to us. They represent development directions and areas that we care about especially. 
They are an internal code of conduct. However, it is not a secret what drives us to the first element" (Mateusz about values)

\section{Clarity}

"Our actions, both for our recipients and partners (suppliers), have clearly defined rules. We run an open policy with companies that cooperate with us. It helps in building trust and free relationships. These in turn help to resolve contentious issues that may arise in a way that does not leave any of the parties with a sense of loss. We communicate the terms and conditions in a clear manner. At the time of any problems, we always strive for dialogue and solution. Transparency gives you clear rules on which we will work and is a clear point in defining our common goals".

\section{Responsibility}

"We understand it not only in the context of social responsibility so popular for several years. Despite the implementation of the CSR strategy, the responsibility in our understanding is much more. For years, Hortimex has been providing information on nutrition as well as food additives and ingredients. It is extremely important for us that we provide data from independent organizations, not just our opinions. Our publications include guidelines of the European Food Safety Authority. We also work with universities in Poland and work for the benefit of consumers' awareness".

\section{Punctuality}

Fast, cheap, good. "We know that it is not possible to fulfil all three obligations. In our business, we always try to fulfil our obligations well. We also define the deadline for implementation. This does not only apply to the logistics of the products supplied, but also to information, trials and joint work on recipes. For us, this is an extremely important element. By combining product design, work on prototypes, we often involve several partners and key service providers. Specifying deadlines is a priority. Timeliness is a plan that we always design accordingly for projects and commitments".

Thanks to the knowledge of technologists, partners and cooperation with scientific and research institutions, proposing solutions is core of Hortimex work. Hortimex attach great importance to provide information. The new proposals are always the most important element for customers. Hortimex want to show not just products or solutions, but what one can achieve and how to achieve this. Technology has been the basis of Hortimex activity for many years. "We have now expanded our consultancy to the whole range of food production". Aspects related to production technology are currently only a part of Hortimex offer. A secure supply chain is their key competence. It does not apply only to the shipment and delivery of goods, but also to secure storage. The timeliness of our deliveries is high. "We obtained this by clearly defining the procedures related to shipping and accepting the goods. The principle is one, we do not promise until we are not sure".

\section{Effectiveness}

The goal of all obligations and relationships with partners is to effectively implement their value propositions. Hortimex partners are producers of ingredients and food additives. On the basis of products, they propose solutions that can be of considerable value 
to customers. Hortimex help meet partners' goals. Provide customers in Poland with continuous access to new solutions.

\section{Flexibility}

Hortimex offer addressed to partners and recipients is flexible. Hortimex operates in a certain framework, therefore the offer has border points. However, we do not have a template according to which. Each of the 18 partners requires a slightly different approach.

\section{Speed}

The implementations must be characterized by appropriate dynamics. Hortimex establish cooperation with new partners at a specific time. This requires proper concentration and intensification of activities. For recipients, this means that the proposals Hortimex present will be implemented in the short term.

"Nine features and values define a certain framework. Is this a description of Hortimex? No, it's just part of what our company is. It is impossible to describe the emotions and satisfaction that appear in our work." (Successors statement).

\section{Clients}

The two most important stakeholder groups Hortimex are ingredients producers usually located outside Poland, and food producers located in Poland. For producers of food ingredients Hortimex is a channel to reach clients in Poland. Companies that decide for exclusive, long-term cooperation they can count on focus on their business goals, professional service and most importantly - full service transparency. It gives you a sense of control on the processes of product implementation on Polish market. Regular reporting, joint visits at the clients, current information exchange and understanding cultural differences between Poland and partner's country of origin build long-term relationships and contribute for business development. "We are loyally fulfilling your duties, expecting in return the same".

\section{What customers say about Hortimex?}

Jacques Maman, Marketing Manager, Tan Nisasta.

"From the beginning of the relationship we are experiencing a perfect business experience cooperation at all its levels. We meet at the company's headquarters in Konin, and we also visit clients throughout Poland with the Hortimex team. The sales results are huge, we have increased our market share in Poland more than $60 \%$. When we opened ours another factory, Omnia Nisasta, we decided that Hortimex will also be distributed the products of this company".

\section{CONCLUSIONS}

Mateusz's journey in family business started in 1994 when he stopped his studies because he realized that the one he had chosen where not suitable for him. His father, Tomasz, said that if he did not want to learn he must start to work. Mateusz did not know what he want to do in his life so the family business was a kind of natural choice, just for the beginning of his professional life. He started with simple things. Because Mateusz was the only one who spoke English, he started to use "yellow pages" to gain new contacts and potential clients. 
"That time it was easy... just put our contact details on web site and in few days someone always contacted us. Now the competition is much bigger" Mateusz says.

"That time it was easy... just put our contact details on web site and in few days someone always contacted us. Now the competition is much bigger" Mateusz says.

In 1996, Mateusz started to work as sales representative. In 90's, there was a big demand for Hortimex's products (mainly food additives) Mateusz results were very impressive. In 2001, his father, appointed him to be a Sales Director. He realized that sales and purchasing departments were completely unorganized and not integrated, he started to introduce changes to optimize work of this two departments. He created so called "product teams" where two employees, one from sales and other from purchasing, started to work together. He though that he was responsible for some aspects of family business but in fact his father still decided about everything. To gain some power and respect Mateusz started to behave like his father: "...I was autocratic and I had impersonal approach...". Between 2006 and 2009, Mateusz did well, but from the time perspective, he said that he was more like an administrator of the company than a manager. Year 2009 was very difficult for the family, because Mateusz's mother died. His father got ill. He was forced to take the position of CEO of the company. Mateusz realized that "...I had no vision what to do next...". Hortimex was in stable position but the problem was that from few years they had no new clients, no new suppliers or partners and the turnover was not improving. Mateusz felt that to grow the company need to change. He started to look for the inspiration. He started to read business books, attend business meetings etc. After years he admitted that he really regret that he stopped studies: "I felt as I opened the open door...It was frustrating...". On one of business meetings, as an exercise, he was asked to write a letter for himself from the future. He left the meeting with empty page... From one side it was disaster but from the other: "...It was like a discovery..." Mateusz said. Few days later he sated in his office in front of this white page and he thought that maybe he will ask the employees to do the same but according to Hortimex? This was the beginning of his big mental change from autocratic manager to transformational leader. In 2011 he asked external business advisors for help in formulating business strategy. Those advisors asked "unconfortable" questions that forced Mateusz and his team to change the way they think about Hortimex. In few months they created "Hortimex 2015 Strategy". Mateusz calls it: " $a$ vision for a succession time...". They transformed business from a wholesaler of food additives to the platform of exchange the knowledge between suppliers of additives and food producers. Meanwhile there was a conflict between Mateusz's father and his wife. Firstly Mateusz tried to be as a mediator. But the conflict intensified. Mateusz decided to quit family business. It was the first time in his life that he defied his father. But with help of the external mediator they they have resolved the conflict. Going back to business, in years 2010-2018, Hortimex, doubled its partners. In 2012 they introduced several corporate governance mechanism and tools, that Mateusz's father could withdraw from the business without feeling lost. Mateusz is proud of what happened, but he is most happy that employees are satisfied and motivated. Taking into account the above considerations, it is possible to refer Mateusz characteristics to the successor's competencies followed by an assessment of their use in the process of succession proposed by Więcek-Janka and Hadryś-Nowak (2016). (Table no 2) 
Table 2. List of successor competences vs successor at Hortimex

\begin{tabular}{|c|c|c|}
\hline Education & acquired qualifications related to the family business industry & Yes/No \\
\hline $\begin{array}{l}\text { Knowledge of } \\
\text { ethics }\end{array}$ & $\begin{array}{l}\text { practical application of the principles of social coexistence on } \\
\text { equal terms. }\end{array}$ & Yes \\
\hline Diligence & $\begin{array}{l}\text { willingness to bear additional burdens and perseverance in } \\
\text { carrying out activities }\end{array}$ & yes \\
\hline $\begin{array}{l}\text { Apprenticeship } \\
\text { in the profes- } \\
\text { sion }\end{array}$ & experiences built in a family business at various positions & yes \\
\hline Experience & business experience & $\begin{array}{l}\text { Yes, at family } \\
\text { business }\end{array}$ \\
\hline Creativity & ability to create something new & $\begin{array}{l}\text { Yes, implement- } \\
\text { ing in family } \\
\text { business new } \\
\text { tools and proce- } \\
\text { dures, change } \\
\text { the previous } \\
\text { business model }\end{array}$ \\
\hline $\begin{array}{l}\text { Communicative- } \\
\text { ness }\end{array}$ & $\begin{array}{l}\text { the ability to clearly express thoughts in a way that is under- } \\
\text { standable to the interlocutor }\end{array}$ & $\begin{array}{l}\text { Yes, looking for } \\
\text { the best pracit- } \\
\text { ices in communi- } \\
\text { cating with the } \\
\text { team }\end{array}$ \\
\hline $\begin{array}{l}\text { Organizational } \\
\text { skills }\end{array}$ & $\begin{array}{l}\text { dealing with the organization of own and other people's activi- } \\
\text { tie }\end{array}$ & Yes \\
\hline Intelligence & $\begin{array}{l}\text { the ability to perceive, analyze and adapt to changes in the en- } \\
\text { vironment }\end{array}$ & yes \\
\hline $\begin{array}{l}\text { Knowledge of } \\
\text { the market }\end{array}$ & $\begin{array}{l}\text { the practical ability to assess market opportunities and threats } \\
\text { in the context of running a family business }\end{array}$ & yes \\
\hline Innovativeness & $\begin{array}{l}\text { using creativity in transforming opportunities into new ideas } \\
\text { and putting them into practice }\end{array}$ & yes \\
\hline Accuracy & $\begin{array}{l}\text { the ability to scrupulously analyze phenomena, draw conclu- } \\
\text { sions along with their practical application }\end{array}$ & yes \\
\hline $\begin{array}{l}\text { Entrepreneur- } \\
\text { ship }\end{array}$ & $\begin{array}{l}\text { a personality trait characterized by openness to changes and } \\
\text { the search for opportunities }\end{array}$ & yes \\
\hline Independence & trait of a person who does not seek help & yes \\
\hline Commitment & $\begin{array}{l}\text { taking active and emotional participation in the implementa- } \\
\text { tion of tasks }\end{array}$ & yes \\
\hline $\begin{array}{l}\text { Stress re- } \\
\text { sistance }\end{array}$ & way of coping with difficult situations & yes \\
\hline Firmness & personality trait associated with tenacity & yes \\
\hline Ambition & striving for a goal, the desire to stand out and strive for success & yes \\
\hline Motivation & \begin{tabular}{|l|} 
conscious willingness to undertake specific tasks \\
\end{tabular} & yes \\
\hline Courage & attitude to defend one's own arguments (challenges) & yes \\
\hline
\end{tabular}

Source: own elaboration based on Więcek-Janka and Hadryś-Nowak (2016).

As we can see from list of successor competences vs successor at Hortimex most of them is suitable for Mateusz. Education is the only the only "element" that does not match 
to the list of successor's competences. Taking into consideration the results of succession process at Hortimex it seems that education, if the rest of the competencies is present, is not that important. Mateusz gained the business education not before joining the family business but during succession.

Mateusz Kowalewski believes that at the very beginning the family should agree on the catalog of values and indicate those that are important to it. It means that business family should start with creating a family order, appoint a family council that will create a constitution: a set of rules for a business family. Mateusz's family didn't do it because they didn't know they could. Only years later they understand certain matters and values that are important and on which they agree and on which they may disagree. They have left the latter in the private sphere and they are not discussed at the family level. They stick to what is important and what binds family together. The decoding of these values in the family is the key to successful succession. It is difficult and it does not happen by itself. Sometimes it is necessary to call in people from the outside who will help not go into dead ends. Kowalewski points out that in his case knowledge succession took place from the very beginning of his work in Hortimex. There is no person in Hortimex today who would know more about the company than Mateusz. However, the succession of power was exemplary for Hortimex. After the conflict, they understood that if his father was able to trust him, he should guarantee him independence and not interfere in day-to-day management. On the other hand, as a manager, Mateusz should treat him not as my dad, but as an owner who wants to know what is going on in the organization without having to look into the nooks and crannies. They have created strategic management tools: a supervisory board led by Mateusz father as the ownership body, as well as a clear vision, formulated mission, strategy, management, control and budgeting systems. Mateusz call his father when he has a dilemma. He needs it and Mateusz also need his support at critical moments. For example, they had several offers to sell the company. The father, who is the majority owner, left these decisions to Mateusz. He trusts Mateusz, but in the company, they have developed tools that allow Mateusz's father to fire me without harming the business. It would probably be quite a shock to the team, but the company is structured in such a way that anyone else can sit in this chair and lead it. Having a sense of a certain uniqueness and value that family bring to the company, they know that they are substitutable.

With the study, author aim to contribute to a better understanding of factors connected with successor's passage from manager to leader in international family business. This endeavor has practical relevance, as many family businesses never embark succession process, and one possible reason is that many family firms do not manage to overcome the challenges of succession. Some practical implications can be derived from the results. Firstly, the successors need to feel responsibility for the family. Secondly, he/she should has the deciding power in some part of the business. As case study shows, conflicts and interactions between family members, when well-managed, might be source of new ideas and solutions. Next to qualifications and constant learning and improving skills, there is also a need for being open minded and ready to change.

The aim of the study was to identify factors that act as driving forces for the successor to become a leader of international family businesses. Based on Mateusz example the following characteristics are considered important for successor: integrity, commitment to 
the family and family business, ability to command the respect of the personnel, decisiveness and interpersonal skills and of course some luck. Firstly, there are the leadership qualities, which every manager must have, whereby it is important that the successor be a visionary entrepreneur. Secondly come management skills. However, even more is expected from the future leaders of family businesses. Thirdly, they must demonstrate commitment and respect for the family. Just as important as the competence is the motivation of the successor. Successions work out a great deal better when the candidate-successor has a strong desire to lead the family business and also finds this a fascinating challenge. Moreover, the successor must have had the freedom to choose to join the family business. Once officially designated as successor, the representative of the next generation is confronted with a new challenge. He must prove himself as the new leader. This does not always go smoothly, because the successor generally finds himself in the phase of succession where he shares the management of the family business with the incumbent leader. The great challenge for the successor is to strike a proper balance between continuity of the management on the one hand and innovation/change on the other. Such change obviously entails a risk of conflicts with the incumbent leader. Some people believe that crises are unavoidable. Yet only a minority of successors achieve credibility by resolutely innovating. Frequently it is more successful not to make all-too sudden changes, but to introduce innovations around an axis of continuity. In this way, the family network - which is based on trust - remains intact, and the successor will also run into less resistance from the incumbent leader. Mateusz admitted that in his path to leadership, above mentioned, there were some important things. Firstly he always felt responsible for the family, especially his wife and children. Secondly, unfortunately but this is true, his mother death was very important to understand this responsibility. Thirdly, when he acted against his father, choosing his wife. This gave him a lot of self-confidence and feeling that he is able to manage things on his own. Mateusz also thinks that this was also a signal for his father to see a leader in him. Last but not least, the openness for external help and support.

A limitation of this study could be seen in its single-country focus on Poland. Also, one could argue that the single-case is a limitation of this study. While this leads to a lack of generalizability of findings in statistical sense, the qualitative approach chosen allowed to explore in depth the transition from being manager to leader. The research highlights the important role of family and business dynamics in this transition from "agent" to "steward“. Yet, further research is needed to test the findings for larger samples, possibly in relation to different contingency factors.

\section{REFERENCES}

Ali, Z., \& Mehreen, A. (2019). Understanding succession planning as a combating strategy for turnover intentions. Journal of Advances in Management Research, 16(2), 216-233.

Banalieva, E.D., \& Eddleston, K.A. (2011). Home-region focus and performance of family firms: the role of family vs non-family leaders. Journal of International Business Studies, 42(8), 1060-1072.

Bednarz, J., Bieliński, T., Nikodemska-Wolowik, A.M., \& Otukoya, A. (2017). Sources of the Competitive Advantage of Family Enterprises: An International Approach Focusing on China, Nigeria and Poland. Entrepreneurial Business and Economics Review, 5(2), 123-142.

Bell, R., \& Pha, T.T. (2020). Modelling the knowledge transfer process between founder and successor in Vietnamese family businesses succession. Journal of Family Business Management, 
ahead-of-print.

Bozer,G. Levin,L., \& Santora, J. (2017). Succession in family business: multi-source perspective. Journal of Small Business and Enterprise Development, 24(4), 753-774, doi.org/10.1108/JSBED-10-2016-0163

Cabrera-Suárez, K., De Saá-Pérez, P., \& García-Almeida, D. (2001). The succession process from a resource- and knowledge-based view of the family firm. Family Business Review, 14 (1), 37-46.

Campbell, K., \& Jerzemowska, M. (2017). Contested takeovers of family firms and socioemotional wealth: a case study. Baltic Journal of Management, 12 (4), 447-463.

Carpenter, M.A., Geletkanycz, M.A., \& Sanders, W.G. (2004). Upper echelons research revisited: Antecedents, elements, and consequences of top management team composition. Journal of Management, 30(6), 749-778, doi.org/10.1016/j.jm.2004.06.001.

Chrisman, J.J., Chua, J.H., Kellermanns, F.W., \& Chang, E.P.C. (2007). Are family managers agents or stewards? An exploratory study in privately held family firms. Family Influences on Firms, 60(10), 1030-1038.

Corbetta, G., \& Salvato, C. (2004). Self-serving or self-actualizing? Models of man and agency costs in different types of family firms: A commentary on "Comparing the agency costs of family and non-family firms: Conceptual issues and exploratory evidence. Entrepreneurship: Theory \& Practice, 28(4), 355-362.

Cromie, S., Stevenson, B., \& Monteith, D. (1995), The management of family firms: An empirical investigation.International Small Business Journal, I3(4), 11-34.

Davidsson, P., Achtenhagen, L., \& Naldi, L. (2010). Small firm growth. Foundations and Trends in Entrepreneurship, 6(2), 69-166.

Davis, J.H., Schoorman, F.D., \& Donaldson, L., (1997). Toward a stewardship theory of management. Academy of Management Review, 22(1), 20-47.

Davis, P.S., \& Harveston, P.D. (1998). The influence of the family on the family business succession process: A multigenerational perspective. Entrepreneurship Theory and Practice, 22(3), 31-53.

Decker, C., Heinrichs, K., Jaskiewicz, P., \& Rau, S.B. (2017). What do we know about succession in family businesses? Mapping current knowledge and unexplored territory. In F.W.Kellermanns \& F. Hoy,(Eds.), The Routledge Companion to Family Business (pp. 15-44). Routledge.

Doern, R. (2009). Investigating barriers to SME growth and development in transition environments. International Small Business Journal, 27(3), 275-305.

Drakopoulou Dodd, S., \& Dyck, B. (2015). Agency, stewardship, and the universal-family firm: a qualitative historical analysis. Family Business Review, 28(4), 312-331.

Dunn, B. (1995). Success themes in Scottish family enterprises: Philosophies and practices through generations. Family Business Review, 8, 17-28.

Dzwigol-Barosz, M. (2019). Prerequisites for successful succession in family company according to its successor. Managerial Economics, 19(2),1-5, doi:https://doi.org/10.7494/manage.2018.19.2.16

Eddleston, K.A., \& Kellermanns, F.W. (2007) Destructive and productive family relationships: A stewardship theory perspective. Journal of Business Venturing, 22(4), 545-565.

Ensley, M.D., \& Pearson, A.W. (2005), An exploratory comparison of the behavioral dynamics of top management teams in family and nonfamily new ventures: cohesion, conflict, potency, and consensus. Entrepreneurship Theory and Practice, 29 (3), 267-284.

Fang, H.C., Randolph, R.V.D.G., Memili, E., \& Chrisman, J.J. (2015). Does size matter? The moderating effects of firm size on the employment of nonfamily managers in privately held family SMEs. Entrepreneurship Theory and Practice, 40 (5), 1017-1039. 
Gómez-Mejía, L. R., Haynes, K. T., Núñez-Nickel, M., Jacobson, K. J. L., and Moyano- Fuentes, J., (2007). Socioemotional wealth and business risks in family-controlled firms: Evidence from Spanish olive oil mills. Administrative Science Quarterly, 52(1), 106-137.

Graves, C., \& Thomas, J. (2008). Determinants of the internationalization pathways of family firms: An examination of family influence. Family Business Review, 21 (2), 151-167.

Hadryś-Nowak, A. (2018). Family Entrepreneurship Orientation in Family Owned SMEs: A Key Resource for Internationalization? Entrepreneurship Business and Economics Review, 6(2), 153-169.

Hambrick, D. (2007). Upper echelons theory: An update. Academy of Management Review, 32(2), 334-343.

Hambrick, D.C., \& Mason, P. (1984). Upper echelons: The organization as a reflection of its top managers. Academy of Management Review, 9(2), 193-206.

Handler, W.C. (1994). Succession in family business: a review of the research. Family Business Review, 7 (2), 133-157.

Ibrahim, A. B., \& Ellis, W. (2003). Family business management, concepts and practices. Kendall/Hunt.

Jensen, M.C., \& Meckling, W. H. (1976). Theory of the firm: Managerial behavior, agency costs and ownership structure. Journal of Financial Economics, 3(4), 305-360.

Klein, S.B. (2007). Non-family executives in family businesses - A literature review. Electronic Journal of Family Business Studies (EJFBS), 1(1), 1796-9360.

Kraus, S., Märk, S., \& Peters, M., (2011). The influences of family on the everyday business of a family firm entrepreneur. International Journal of Entrepreneurship and Small Business, 12(1), 82-100.

Le Breton-Miller, I., Miller, D., \& Lester, R. H. (2011). Stewardship or agency? A social embeddedness reconciliation of conduct and performance in public family businesses. Organization Science, 22(3), 704-721.

Lewandowska A., Więcek-Janka E., \& Hadryś-Nowak A. (2017). Raport z badania: Firma Rodzinna to Marka. Instytut Biznesu Rodzinnego.

Liu, J. (2018). Successors' Characteristics, Preparation, Innovation, and Firm Performance: Taiwan and Japan. International Business Research, 11(9), 1-12.

Loane, S., Bell, J.D., \& McNaughton, R. (2007), A cross-national study on the impact of management teams on the rapid internationalization of small firms. Journal of World Business, 42(4), 489-504.

Martin, W.L., \& Lumpkin, G.T. (2004). From entrepreneurial orientation to family orientation: Generational differences in the management offamily businesses. Frontiers of entrepreneurship research. Wellesley, MA: Babson College.

Menéndez-Requejo, S. (2005). Growth and internationalization of family businesses. International Journal of Globalisation and Small Business, 1, 122-133.

Morck, R., \& Yeung, B., (2003). Agency problems in large family business groups. Entrepreneurship: Theory \& Practice, 27(4), 367-382.

Morris, M.H., Williams, R.O., Allen, J.A., \& Avila, R.A. (1997). Correlates of success in family business transitions. Journal of Business Venturing, 12 (5), 385-401.

Pierce, J.L., Kostova, T., \& Dirks, K.T. (2001). Toward a theory of psychological ownership in organizations. Academy of Management Review, 26(2), 298-310.

Reid, R., Dunn, B., Cromie, S., \& Adams, J. (1999). Family Orientation in family firms: A model and some empirical evidence. Journal of Small Business and Enterprise Development, 6(1), 55-66.

Schulze, W.S., Lubatkin, M.H., \& Dino, R.N (2003). Toward a theory of agency and altruism in family firms. Journal of Business Venturing, 18(4), 473-490. 
Sharma, P. (2004). An overview of the field of family business studies: Current status and directions for the future. Family Business Review, 17(1), 1-36.

Shukla, P.P. Carney, M., \& Gedajlovic, E. (2014). Economic theories of family firms. In L. Melin, M. Nordqvist, \& P. Sharma (Eds.), Sage Handbook of Family Business Studies Thousand Oaks (pp. 100-118). Sage Publications Ltd.

Schwartz, M. (2018). Wave of successions in German SMEs: 240,000 successors wanted by 2019, KfW Research Focus on Economics, 197.

Vera, C.F., \& Dean, M.A. (2005). An examination of the challenges daughters face in family business succession. Family Business Review,18 (4), 321-345.

Wach, K. (2017). Exploring the Role of Ownership in International Entrepreneurship: How does Ownership Affect Internationalisation of Polish Firms?. Entrepreneurial Business and Economics Review, (4), 205-224. https://doi.org/10.15678/EBER.2017.050410

Więcek-Janka, E., \& Hadryś-Nowak, A. (2016). Kompetencje sukcesorskie - profil wstępny. Przedsiębiorczość i Zarzqdzanie, XVII (6) cz. III, 61-72.

\section{Author}

\section{Alicja Hadryś-Nowak}

Associate Professor of the Department of International Management at Faculty of International Business and Economics of Poznań University of Economics. PhD in economics. Her current research interests include management of family-owned businesses, internationalisation and branding and women entrepreneurship. Member of IFERA since 2010. Visiting Professor at Lethbridge University (Canada), Universita Politecnica delle Marche (Italty) and Jonkoping Business School (Sweden). Expert in Family Business Institute in Poznań.

Correspondence to: $\mathrm{Dr}$ hab. Alicja Hadryś-Nowak, Poznań University of Business and Economics, Faculty of International Business and Economics, International Management Chair, e-mail: alicja.hadrys@ue.poznan.pl

ORCID (1) http://orcid.org/0000-0003-2684-9910

\section{Acknowledgements and Financial Disclosure}

The author would like to thank the anonymous referees for their useful comments, which allowed to increase the value of this article.

\section{Copyright and License}

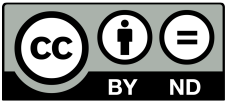

This article is published under the terms of the Creative Commons

Attribution - NoDerivs (CC BY-ND 4.0) License

http://creativecommons.org/licenses/by-nd/4.0/

Published by the Centre for Strategic and International Entrepreneurship - Krakow, Poland 